Tanjak: Jurnal Sejarah dan Peradaban Islam, Vol. I No. 1, 2020

\title{
PERAN MAHMUD GHAZNI TERHADAP PERKEMBANGAN PERADABAN ISLAM, 388-421 H/ 998-1030 M
}

\author{
Rahmawati ${ }^{1}$, Nor Huda $\mathrm{Ali}^{2}$, Otoman ${ }^{3}$ \\ ${ }^{123}$ Universitas Islam Raden Fatah, Palembang, Indonesia \\ *Email: spiadab_uin@radenfatah.ac.id
}

\begin{abstract}
Abstrak
Topik penelitian ini perlu diteliti karena pada masa itu banyak peristiwa yang terkait dengan gambaran perjuangan banyak tokoh Islam dalam memajukan Islam terutama Mahmud Ghazni. Pada masa pemerintahan Mahmud Ghazni peradaban Islam mengalami kemajuan yang pesat serta pada masa pemerintahan Mahmud Ghazni banyak kemajuan di bidang pendidikan dan perekonomian. Mahmud Ghazni adalah seorang yang menguasai Islam dan sangat memiliki pengaruh serta kekuatannya saat peperangan dan kerap menang atas musuhnya hingga khalifah Al-Qadir Billah memberi gelar Yamin addaulah yang artinya orang yang diandalkan pemerintah serta Amin Addaulah yang artinya yang dipercaya pemerintah. Mahmud Ghazni diketahui selaku umat sholeh serta memiliki janji yang kuat dalam bidang keilmuan serta perkembangan. Masalah yang dibahas dalam penelitian ini sebagai berikut. Pertama, bagaimana gambaran umum Dinasti Ghaznawiyah dalam sejarah Islam? Kedua, bagaimana perkembangan Dinasti Ghaznawiyah pada masa Pemerintahan Mahmud Ghazni? Ketiga, bagaimana strategi yang dilakukan oleh Mahmud Ghazni dalam memajukan peradaban Islam? Dalam penelitian ini jenis penelitian yang digunakan adalah penelitian kualitatif yang bertumpuh pada bahanbahan pustaka yang relevan dengan tema penelitian sedangkan, metode yang digunakan ialah penelitian sejarah (historical research), yaitu berupaya mengetahui serta membuat rekontruksi sejarah masa lampau secara sistematis dan obyektif berkaitan peran Mahmud Ghazni terhadap perkembangan peradaban Islam (388-421 H/ 998-1030 M), dengan cara mengumpulkan, mengevaluasi bukti-bukti kuat untuk menegakkan fakta dan mendapatkan kesimpulan yang kuat. Hasil penelitian pada penelitian ini adalah pertama, Alpataqin adalah sebagai perintis berdirinya Dinasti Ghaznawiyah, sementara Sabuktaqin mampu membentuk kekuatan Dinasti yang mapan dan wilayah yang luas sehingga kemudian diakui keberadaannya oleh Baghdad. Kedua, Pemerintahan Dinasti Ghaznawiyah mengalami kejayaan pada masa pemerintahan Mahmud Ghazni yang berkuasa selama lebih kurang 34 tahun. Kekuatan yang dimilikinya dapat dipergunakan untuk memperluas wilayah kekuasaan hingga mencapai wilayah India, hingga berhasil menaklukan Peshawar, Kashmir, dan Bathinda pada 391-394 H/1001-1004 M. Punjab dikuasai pada 1006 M, Kangra pada 1009, Baluchistan pada 402-403 H/10111012 M, kemudian Delhi pada 405-406 H/1014-1015 M. Wilayah yang luas dan sumber kekayaan yang melimpah, membuat ekonomi negeri ini sangat kuat, sehingga dapat dimanfaatkan untuk kemakmuran negeri. Pertama, Alpataqin adalah sebagai perintis berdirinya Dinasti Ghaznawiyah, sementara Sabuktaqin mampu membentuk kekuatan Dinasti yang mapan dan wilayah yang luas sehingga kemudian diakui keberadaannya oleh Baghdad. Ketiga, Mahmud Ghazni dalam memajukan peradaban Islam di India, melakukan beberapa strategi untuk dapat mencapai masa kejayaan serta kemajuan Islam. Adapun strategi yang dilakukan Mahmud Ghazni untuk memajukan peradaban Islam di India dengan melakukan kebijakan dalam bidang politik dan pemerintahan, dalam bidang militer, melakukan beberapa kebijakan dalam bidang ekonomi serta kebijakan dalam bidang sosial budaya dan keagamaan.
\end{abstract}

Kata-kata kunci: Mahmud Ghazni, Dinasti Ghaznawiyah, perkembangan peradaban Islam 
Tanjak: Jurnal Sejarah dan Peradaban Islam, Vol. I No. 1, 2020

\begin{abstract}
The topic of this research needs to be investigated because at that time there were many events related to the description of the struggle of many Islamic figures in advancing Islam, especially Mahmud Ghazni. During the reign of Mahmud Ghazni Islamic civilization experienced rapid progress and during the reign of Mahmud Ghazni much progress in the fields of education and the economy. Mahmud Ghazni was a man who controlled Islam and had a lot of influence and power during wars and often won over his enemies until the caliph Al-Qadir Billah gave him the title Yamin addaulah which means people who are trusted by the government and Amin Addaulah which means trusted by the government. Mahmud Ghazni is known as a pious person and has a strong promise in the field of science and development. The problems discussed in this study are as follows. First, what is the general picture of the Ghaznavid dynasty in Islamic history? Second, how was the development of the Ghaznawiyah dynasty during the reign of Mahmud Ghazni? Third, what is the strategy used by Mahmud Ghazni in advancing Islamic civilization? In this study, the type of research used is qualitative research that relies on library materials that are relevant to the research theme, while the method used is historical research, which seeks to find out and make a systematic and objective reconstruction of past history related to the role of Mahmud Ghazni on the development of Islamic civilization (388-421 $H / 998-1030$ AD), by collecting, evaluating strong evidence to establish facts and get strong conclusions. The results of the research in this study are first, Alpataqin was the pioneer of the founding of the Ghaznawiyah Dynasty, while Sabuktaqin was able to form an established dynasty power and a wide area so that it was later recognized by Baghdad. Second, the government of the Ghaznawiyah dynasty experienced glory during the reign of Mahmud Ghazni who ruled for approximately 34 years. Its power can be used to expand its territory to reach the territory of India, to successfully conquer Peshawar, Kashmir, and Bathinda in 391-394 H/1001-1004 AD. Punjab was controlled in 1006 AD, Kangra in 1009, Baluchistan in 402-403 H. /1011-1012 AD, then Delhi in 405406 H/1014-1015 AD. The vast territory and abundant sources of wealth make this country's economy very strong, so that it can be used for the prosperity of the country. First, Alpataqin was the pioneer of the founding of the Ghaznawiyah dynasty, while Sabuktaqin was able to form an established dynasty and a large area that was later recognized by Baghdad. Third, Mahmud Ghazni in advancing Islamic civilization in India, carried out several strategies to be able to achieve the heyday and progress of Islam. Mahmud Ghazni's strategy is to advance Islamic civilization in India by carrying out policies in the fields of politics and government, in the military field, carrying out several policies in the economic field as well as policies in the socio-cultural and religious fields.
\end{abstract}

Keywords: Mahmud Ghazni, Ghaznawiyah dynasty, development of Islamic civilization peradaban 


\section{A. PENDAHULUAN}

Ghaznawiyah merupakan nama suatu dinasti yang berkedudukan di kota Ghazna serta menguasai di wilayah India Utara dan Afghanistan. ${ }^{1}$ Dinasti tersebut didirikan Subektegin sebagai panglima dan gubernur Bani Saman yang berasal dari Turki. Usia Dinasti tersebut lebih dari 200 tahun (366 H/977 M - 582 H/1186 M) di Iran Timur dan di wilayah yang sekarang menjadi Afghanistan, amir Dinasti Gaznawiyah menyandang gelar amir, sekalipun sejarawan menyebut mereka sultan. ${ }^{2}$ Alfataqin merupakan mantan budak penduduk Turki yang mempunyai kedudukan terhormat di kalangan Samaniyun. Dia diangkat sebagai penguasa di kota Herat dan Ghazna. Pada waktu pamornya baik di mata penduduk serta dapat mendirikan pemerintahan di wilayah Afghanistan, Punjab dan Pakistan.

Dinasti Ghaznawiyah mengalami kemajuan ketika di bawah pemerintahan Mahmûd Ghazni yang bisa terihat pada beberapa aspek. Wilayah Dinasti Ghaznawiyah pada masa Sabuktigin diperluas melalui penaklukkan beberapa wilayah di Kusdar dan Sijistan. Bahkan menunjukkan kemampuan dalam mempertahankan Iran bagian barat dan Transoxania dari serbuan Bani Saljuk. ${ }^{3}$ Ketika Mahmud Ghazni menduduki pucuk pemerintahan, pencapaian puncak terlihat pada kemajuan bidang politik. ${ }^{4}$ Selain kecakapan dalam pemerintahan, prestasi Mahmud Ghazni yang gemilang juga ditunjang dari beberapa faktor, diantaranya: (1) raja-raja di India yang saling bertentangan, sehingga persatuan menjadi terpecah ketika mendapatkan penyerangan dari Mahmud Ghazni, ketika masa pemerintahan Sabuktiqin dalam penaklukkan Punjab dari Dinasti Rajput, (2) faktor geografis, Ghazna merupakan ibukota di dataran tinggi yang sangat srategis untuk melakukan pengamatan dan melakukan kontrol lalu lintas ke India, (3) faktor ideologis tentara Mahmud dikorbarkan oleh semangat jihad dan kefanatikan terhadap pemimpin berkharismatik. Selain hal tersebut, harapan mereka juga memperoleh harta rampasan perang yang banyak.

Mahmud Ghazni adalah seorang yang menguasai Islam dan sangat memiliki pengaruh serta kekuatannya saat peperangan dan kerap menang atas musuhnya hingga khalifah Al-Qadir Billah ${ }^{5}$ memberi gelar Yamin addaulah yang artinya orang yang diandalkan pemerintah serta Amin Addaulah yang artinya orang yang dipercaya pemerintah). Mahmud Ghazni (2 November $998 \mathrm{M}-$ 30 April 1030 M) merupakan Sultan ketiga dari Dinasti Ghaznawiyah. Tokoh-tokoh sekte Syafi'i yang terkenal dan sukses pada masa itu kerap memberi kekuatan terhadap Sunni atau Ahlusunah waljamaah fahan serta melawan para bid'ah, seperti Jahmiyah dan Qamarisah yang dipengaruhi oleh kepercayaan Hindu. Mahmud Ghazni diketahui selaku umat sholeh serta memiliki janji yang kuat dalam bidang keilmuan serta perkembangan.

Fokusnya pada bidang keilmuan yang cukup berpengaruh pada masa kekhalifahannya (998$1030 \mathrm{M}$ ) bisa diketahui melalui aktivitas keilmuan antara lain: 1) Memulai penyusunan tafsir AlQur'an sesuai dengan ilmu Nahwu serta Neurology dan berasal dari Hadis Otentik, 2) Mengembangkan perguruan untuk melakukan proses pembelajaran, 3) Menyarankan ulama-ulama serta filosof Islam yang mencakup Al-Biruni, Ibnu Sina, Abu Nasr al-Arraq serta Ibn Khamar Abu Sahl al-Masihi supaya bisa memanfaatkan pengetahuan yang dimilikinya. ${ }^{6}$

Pada masa pemerintahannya Ghazna tidak hanya untuk mempertahankan wilayah intensitas peperangan, namun wilayah paling indah di Asia Tengah para teolog berkumpul, mengubah hal tersebut selaku suatu Dinasti yang paling maju juga sejahtera pada wilayah tersebut. Ghazna tidak

\footnotetext{
${ }^{1}$ Ahmad Syalabi, Sejarah dan Kebudayaan Islam, terj. Mukhtar Yahya (Jakarta: Pustaka al-Husna, 1997), hlm. 165

${ }^{2}$ Ibid., hlm. 120.

${ }^{3}$ W. Montgomery Watt, Kejayaaan Islam, terjemahan Kartono Hadikusumo, (Yogyakarta: Tiara Wacana, 1990), hlm. 218.

${ }^{4}$ Istianah Abu Bakar, Sejarah Peradaban Islam (Malang: UIN-Malang Press, 2008), hlm. 87

${ }^{5}$ Ira M. Lapidus, Sejarah Sosial Umat Islam, terjemahan Ghufron A. Mas'adi (Jakarta: PT. Raja Grafindo, 2000), hlm. 221.

${ }^{6}$ Dewan Redaksi, Ensiklopedi Islam (Cet. II, Jakarta: PT. Ichtiar Baru Van Hoeve, 1994), hlm. 155.
} 
hanya menjadi perang pertahanan, namun juga menjadi tempat para pengacara, ulama, ahli hukum, bahasa, ilmu kebatinan, dan filsafat untuk berkumpul. Di kawasan pembangunan, khususnya pada wilayah Ghazna, Mahmud mendirikan keraton di Afghanistan, Shal, mendirikan taman Sad Hasan, istana keraton Alphard serta taman di mana dikuburkan selanjutnya. Di samping itu, Mahmud Ghazni pun mendirikan masjid mewah di Ghazna yang dikenal sebagai Al-Falaq Flow, juga dilakukan pembangunan sekolah lengkap dengan fasilitas perpustakaan.

Sepeninggalan Mahmud Ghazni, Dinasti Ghaznawiyah menunjukkan tanda-tanda kemunduran. Peristiwa tersebut dikarenakan penurunan sumber pendapatan negara, bahkan sesudah Tughrul Bek, Dinasti Saljuk menguasai Khurasan dan beberapa wilayah bagian Timur memisahkan diri dari pemerintahan Dinasti Ghaznawiyah. Pemisahan wilayah ini adalah peristiwa politik yang tidak stabil, dengan demikian sejumlah wilayah mendirikan kerajaan-kerajaan Islam kecil. Namun, keluarga Turkestan dan Khan serta keluarga Saljuk dari Persia membagi wilayah kekuasaanya di Dinasti Ghaznawiyah. Sedangkan, kelompok Ghuriyah dari Afghanistan menyerang kekuasaan Dinasti Ghaznawiyah. ${ }^{7}$ Ketika masa kekuasaan Mas'ud ibnu Mahmud Ghazni, Dinasti Ghaznawiyah mengalami kemunduran luar biasa, sebab wilayah Khawarizm dan Khurasan jatuh ke tangan Saljuk. Sekitar abad ke-11 M, Mas'ud disibukan dengan peperangan melawan kekuatan Bani Saljuk yang ingin menguasai Afghanistan Barat dan Sijistan. Sejak tahun 1040-1059 M peperangan berlangsung terus-menerus antara Bani Saljuk dengan Dinasti Ghaznawiyah. Perdamaian antara Dinasti Saljuk dengan Dinasti Ghaznawiyah terjadi sesudah Bani Ibrahim berkuasa. Perjanjian tersebut berlangsung selama setengah abad. Isi perjanjian tersebut ialah Ibrahim harus menyerahkan wilayah Afghanistan Barat kepada Bani Saljuk, sehingga wilayah wilayah kekuasaan Ghaznawiyah hanya mencakup wilayah India Utara dan Afghanistan bagian Timur. ${ }^{8}$

Berdasarkan uraian di atas, maka peneliti tertarik untuk menulis penelitian ini yang mengkaji tentang biografi tokoh tersebut, kebijakan-kebijakan yang dibuat dalam memajukan Islam dan perjalanan perjuangan tokoh tersebut dalam perkembangan peradaban Islam. Maka dari itu peneliti mengambil judul "Peran Mahmud Ghazni Terhadap Perkembangan Peradaban Islam Pada, 388-421 H/998-1030 M".

Perumusan masalah sebagai penjabaran dari identifikasi masalah dan pembatasan masalah. Maka tujuan perumusan masalah ialah untuk memfokuskan pikiran serta mengarahkan cara berpikir kita. Berdasarkan dari judul penelitian, maka penulis merumuskan beberapa masalah dalam tulisan ini sebagai berikut. Pertama, bagaimana gambaran umum Dinasti Ghaznawiyah dalam sejarah Islam? Kedua, bagaimana perkembangan Dinasti Ghaznawiyah pada masa Pemerintahan Mahmud Ghazni? Ketiga, bagaimana strategi yang dilakukan oleh Mahmud Ghazni dalam memajukan peradaban Islam?

\section{B. METODOLOGI PENELITIAN}

Jenis penelitian dalam penelitian ini ialah penelitian kualitatif yang bertumpu pada bahan-bahan pustaka yang relevan terhadap tema penelitian. Sedangkan metode yang digunakan ialah penelitian sejarah (historical research), yaitu berupaya mengetahui serta membuat rekontruksi sejarah masa lampau secara obyektif dan sistematis berkaitan peran Mahmud Ghazni terhadap perkembangan peradaban Islam (388-421 H/ 998-1030 M), dengan cara mengumpulkan, melakukan evaluasi terhadap pembuktian-pembuktian dalam mengungkapkan kebenaran serta mendapatkan simpulan yang kuat. ${ }^{9}$

Kuntowijoyo memberi pendapat "metode sejarah adalah implementasi pengguna teknis mengenai penyajian, interpretasi, kritik dan bahan sejarah. Pada penelitian ini, metode penelitian

\footnotetext{
${ }^{7}$ Samsul Munir Amin, Sejarah Peradaban Islam (Jakarta: Amzah, 2009), hlm. 276

${ }^{8}$ Ibid., hlm 279

${ }^{9}$ Endah Sri Hartatik, Metode Penelitian Sejarah (Yogyakarta: Magnum Pustaka Utama, 2018), hlm 24
} 
sejarah yang dipakai mencakup 4 tahapan penelitian sejarah dengan tujuan agar melakukan rekonstruksi pada fenomena sejarah." ${ }^{10}$ Kuntowijoyo merumuskan 4 tahapan penelitian sejarah tersebut yaitu:

\section{Pemilihan Topik}

Tahapan pertama ialah memilih topik. Topiknya ditentukan sesuai dengan kadar ketertarikan peneliti pada tema yang hendak dipilih dan memperhatikan tingkatan intelektualitas yang berhubungan terhadap tema yang diamati pada penelitian. Melalui hal tersebut, peneliti menjadi tidak kesulitan dalam membuat rumusan permasalahan yang hendak diteliti. Karena hal tersebut peneliti membuat judul "Peran Mahmud Ghazni terhadap perkembangan peradaban Islam, 388-421 H/ 998-1030 M".

\section{Heuristik (Pengumpulan Sumber)}

Sesudah memilih topik ataupun tema untuk diteliti, dengan demikian tahapan berikutnya ialah menghimpun sumber-sumber sejarah terkait topik yang dipilih ataupun dipahami pada istilah heuristik. ${ }^{11}$ Istilah "heuristik" diambil berdasarkan istilah "heuriskien" yang menurut bahasa Yunani artinya "menemukan." Pada konteks penulisan sejarah, umumnya heuristik dimaknai sebagai aktivitas sejarahwan dalam menghimpun sumber-sumber sejarah. Saat menyusun skripsi dengan judul "Peran Mahmud Ghazni Terhadap Perkembangan Peradaban Islam, 388$421 \mathrm{H} /$ 998-1030 M" peneliti menghimpun sejumlah sumber sejarah terkait topik yang dipilih dalam bentuk: buku-buku yang terdapat pada perpustakaan, baik perpustakaan Universitas Negeri Islam (UIN) Raden Fatah Palembang, perpustakaan Fakultas Adab dan Humaniora, serta perpustakaan pribadi.

\section{a. Sumber Primer}

Louis Gottchalk mengemukakan "Sumber primer sebagai sumber catatan saksi, pengamat ataupun cerita, yang memuat kesaksian dimana orang-orang itu melihat kejadian tersebut, ataupun menjadi tokoh pada kejadian tersebut. ${ }^{12}$ Pada penelitian ini tidak menggunakan sumber primer namun menggunakan sumber kedua yaitu sumber sekunder.

b. Sumber Sekunder

Sumber sekunder merupakan catatam saksi terhadap seseorang yang tidak menjadi saksi mata, yaitu berdasarkan informasi dari seseorang yang tidak berada di tempat saat kejadian yang diceritakan. Sumber sekundernya ialah sumber-sumber pustaka dari karya tulis sejumlah peneliti ataupun sejarahwan, buku-buku, karya ilmiah yang melaksanakan pengkajian terkait permasalahan yang berhubungan ataupun memiliki pendekatan pada penelitian yang dilakukan.

\section{Verifikasi}

Sesudah mendapatkan sumber-sumber penulisan sejarah yang diperlukan, maka tahap berikutnya adalah Verifikasi dalam penelitian ini menggunakan dua tahap yang perlu dilakukan untuk memverifikasi sumber data yang sudah didapat yakni melalui (1) data reduction (pereduksi data); (2) data display (penyajian data). berikut ini adalah tahapan sesudah data diperoleh sebagai berikut:

a. Reduksi Data

Data reduction berarti meringkas, menentukan substansi dan fokus terhadap sesuatu yang pokok. Pada proses pereduksian data dapat memberi deskripsi secara tepat serta memudahkan penulis dalam mengumpulkan data berikutnya kemudian mencari jika

\footnotetext{
${ }^{10}$ Kuntowijoyo, Metodologi Sejarah (Yogyakarta: Tiara Wacana, 2003), hlm. 29

${ }^{11}$ Suhartono W. Pranoto, Teori dan Metodologi Sejarah (Yogyakarta: Graha Ilmu, 2001), hlm. 15.

${ }^{12}$ J.W. Best, Metodologi Penelitian, terjemahan Sanapsiah Faisal dan Mulyadi (Surabaya: Usaha Nasional, 1999), hlm. 31
} 
dibutuhkan. Pereduksian tersebut bisa melalui alat elektronik, contohnya komputer mini yang memberi kode terhadap hal-hal khusus. ${ }^{13}$

b. Penyajian Data (data display)

Sesudah melakukan pereduksian data, dengan demikian tahap berikutnya ialah menguraikan data. Penguraian data sebagai kumpulan data yang terstruktur memberikan peluang tahap menarik kesimpulan dan mengambil keputusan. Dalam menyajikan data dipakai untuk mengembangkan pengkajian masalah dan sebagai tolak ukur untuk bertindak sesuai analisis serta pemahaman data.

\section{Interpretasi}

Interpretasi ataupun yang dinamakan analisis fakta sejarah dilaksanakan penulis dalam mewujudkan definisi aspek-aspek yang mengakibatkan sebuah kejadian yang muncul. Interpretasi bisa dilaksanakan melalui perbandingan data dalam mengungkapkan kejadian apa yang dialami pada suatu periode. Pada tahapan tersebut, peneliti menganalisis sejarah pada sumber data yang sudah diverifikasi serta bisa dipertanggungjawabkan jika ada sumber data yang tidak sama pada cakupan permasalahan serupa, dengan demikian penulis melakukan perbandingan terhadap data-data supaya menjadi sinkron dalam menetapkan data yang paling benar.

\section{Historiografi}

Historiografi adalah cara menulis, memaparkan, ataupun melaporkan hasil penelitian historis yang sudah dilaksanakan dan dicantumkan dalam bentuk skripsi. Historiografi merupakan upaya dalam merumuskan kejadian dengan cara sistematik, kronologis, serta logis melalui penerapan bukti-bukti sejarah yang didapatkan dan demikian menghasilkan sebuah cerita alamiah.

\section{HASIL DAN PEMBAHASAN}

\section{Dinasti Ghaznawiyah (388-421 H/998-1030 M) Dalam Lintasan Sejarah Islam}

Ghaznawiyah ialah daulah baru yang berdiri di Ghazna di tenggara Afghanistan tahun 366 H/976 M memiliki peran yang cukup besar di sejarah Islam khususnya pada anak benua India. Raja Bani Saman, Abdul Malik ibnu Nuh pada tahun 350 H/961 M mengangkat Alpataqin menjadi Gubernur di Hijah, Barat laut Afghanistan. Namun, berakhirnya jabatan tersebut saat rajanya wafat dan Mansur bin Nuh menggantikannya. Sementara itu, tepatnya tahun 351 H/962 M Alpatiqin melaksanakan ekspansi ke arah timur, yaitu ke Afghanistan bagian timur. Alpatiqin melakukan penaklukkan dan menguasai wilayah ini tepatnya di kota Ghazna beserta beberapa wilayah di sekitarnya. ${ }^{14}$

Alpataqin wafat pada tahun $352 \mathrm{H} / 963$ dan digantikan oleh keturunannya yaitu Ishaq. Namun, ternyata Ishaq dalam memimpin pemerintahan kurang cakap dan harus merelakan singgasananya jatuh ketangan keturunan Turki yaitu Baltaqin yang selanjutnya digantikan juga oleh Piri. Sementara itu, pada tahun 366 H/977 M Piri diserang oleh Ishaq. Sementara itu, Sabuktaqin hanya menduduki kekuasaan hingga tahun 387 H/997 M. ${ }^{15}$ Sabuktaqin diangkat untuk menggantikan pemerintahan sebelumnya berdasarkan atas pertimbangan moral dan etika. Dia terkenal di kalangan pembesar Dinasti Samaniyah sebagai orang cerdas, taat beragama, mempunyai sifat iffah dan murah hati bahkan pandai dalam strategi perang. Namun, di balik semua itu kemungkinan bahwa pengangkatannya bertujuan mempermudah Dinasti Samaniyah mengendalikannya dari pada mengendalikan orang seperti Piri yang belum dikenal olehnya.

\footnotetext{
${ }^{13}$ Sugiyono, Metode Penelitian Kombinasi (Mix Methods), (Bandung:Alfabeta, 2015), hlm. 247

${ }^{14}$ Fahsin M. Faal, Sejarah Kekuasaan Islam (Cet.I, Jakarta:CV Artha Rivera,2008), hlm.89.

${ }^{15}$ Yosoef Syou'ib, Sejarah Daulah Abbasiyah II (Jakarta: Bulan Bintang, 1997), hlm. 240.
} 
Sabuktaqin menjadi pemimpin dengan perjanjian pasukan militernya sebagai penguasa Dinasti Ghaznawiyah tahun 366 H/977 M. Awal mula dia sudah mempunyai Khurasan yang diberikan oleh raja samaniyah yaitu Nuh bin Mansur, sebagai tanda kehormatannya dikarenakan jasanya dalam keberhasilan menghalau pemberontakan di Transoxiana. Sesudah Sabuktaqin diangkat menjadi pemimpin, kemudian dia memperluas daerah kekuasaannya di Timur sampai ke Peswayar, di Persi. Selanjutnya Kabul sudah dikuasainya dan ekspansinya mengarah ke India. ${ }^{16}$ Sabuktaqin berjuang selama 20 tahun dan wafat tahun 387 H/997 M, Selanjutnya digantikan anaknya yaitu Mahmud Ghazni, yang terkenal dengan gelar Mahmud Ghazni 388 H/999 M, namun masih mengatasnamakan dirinya sebagai gubernur Dinasti Samaniyah, maka saat terjadi pemberontakan di Balkh terhadap Dinasti Samaniyah, Mahmud Ghazni ikut serta membantu raja Samaniyah yaitu Abd malik bin Mansur. Di tahun 394 H/1004 M, Muntasir, penguasa terakhir Bani Samani tewas pada peperangan. Sesudah hancurnya Dinasti Samaniyah tersebutlah Mahmud Ghazni dengan sah diakui khalifah Abbasiyah yaitu khalifah Al-Qadir serta memberi gelari yamin Al-daulah. ${ }^{17}$ Pusat kekuasaan Dinasti Ghaznawiyah adalah kota Ghazna (masuk Afghanistan). Daerah tersebut mencakup bagian timur Pakistan, Afganistan, Iran, serta sejumlah daerah India. ${ }^{18}$

\section{Perkembangan dan Kejayaan Dinasti Ghaznawiyah}

Seperti yang sudah dijelaskan, bahwa Sabuktaqin sebagai orang yang mendirikan Dinasti Ghaznawiyah memiliki kekuasaan dan menempatkan landasan-landasan pada pemerintahan yang berkembang, kemudian sampai pada masa keemasan di zaman kekuasaannya, yakni di zaman Mahmud Ghazni. Pencapaian-pencapaian yang diperoleh yakni dalam hal ilmu pengetahuan, politik, dan kebudayaan.

a. Bidang Politik

Keberhasilan yang selalu didapatkan Mahmud Ghazni memperlihatkan adanya kekuasaan militer maupun politik Ghaznawiyah. Hal itu memberi dampak terhadap perekonomian yang semakin maju. Melalui hal tersebut, Ghaznawiyah memperoleh banyak harta yang telah dirampas selain pajak. Harta itu dipakai pula selaku pendanaan pelaksanaan Negara, salah satunya dipakai dalam mengembangkan budaya dan ilmu pengetahuan, dipakai juga untuk alternatif operasional memberi gaji untuk tentara angkata perang dan digunakan juga untuk biaya berekspedisi.

Dinasti Ghaznawiyah mampu menjalankan ekspansi di sejumlah daerah. Keseluruhan tersebut tentunya juga dipengaruhi oleh peranan dan upaya dari tokoh-tokoh yang menguasai Dinasti Ghaznawiyah dalam memperkuat politik melalui perluasan wilayah kekuasaan di India. Harus dipahami bahwa Mahmud Ghazni sudah menyerang ataupun melakukan perlawanan sebanyak 27 kali pada jangka waktu 26 tahun yakni di tahun 391-417 H/1000$1026 \mathrm{M}^{19}$

Harus diketahui bahwasannya Mahmud Ghazni memusnahkan kota ataupun daerah yang ditaklukinya dengan tidak merata seluruh bumi. Walaupun terdapat kebanggan tersendiri dikenal sebagai penghancur berhala, dirinya tidak pernah mengenal pembunuhan massal. Dikarenakan diserang oleh pasukan Mahmud Ghazni, hal itu membuat raja-raja Hindu di India menjadi ketakutan, di antaranya raja hadarata yang memutuskan untuk menganut agama Islam dengan lebih kurang 10.000 orang pengikut di tahun $411 \mathrm{H} / 1020 \mathrm{M}^{20}$

Pada masa pemerintahan Mahmud Ghazni, dalam sektor politik sampai pada masa kejayaannya. Dinasti Ghaznawiyah yang dulunya merupakan kerajaan kecil dan memiliki

\footnotetext{
${ }^{16}$ Ibid., hlm. 170.

${ }^{17}$ Ibid., hlm. 170-171.

${ }^{18}$ Hasan Ibrahim Hasan, Sejarah dan Kebudayaan Islam, jilid III, terjemahan Djahdan Humam (Yogyakarta: Kota Kembang, 1989), hlm. 94.

${ }^{19}$ Busman Edyar, Sejarah Perdaban Islam (Jakarta: Pustaka Asatruss, 2009), hlm. 953.

${ }^{20}$ Ibid., hlm. 155.
} 
banyak bangunan runtuh karena peperangan, kemudian dibangun lagi menjadi wilayah perkotaan besar yang dapat dijadikan pusat untuk mengembangkan ilmu pengetahuan maupun budaya. Wilayah itu lebih luas dimulai dengan sungai Ozus di Amudarya (Asia Tengah) hingga sungai Indus (pesisir selatan India), dimulai dari pinggiran laut Kaspia di utara sampai dengan India tepatnya di sungai Gangga. ${ }^{21}$

b. Bidang Ekonomi

Daerah yang pernah ditaklukan Dinasti Ghaznawiyah ialah Khurasan yang banyak mendatangkan perkembangan pada segi perekonomian. Berdasarkan pendapat Watt bahwa "menurut Mahmud Ghazni, Khurasan sangat penting dikarenakan kekayaan dan kemakmurannya didapatkan berdasarkan pungutan pajak-pajak sehingga cukup mudah untuk menaklukkan India."

Al-Sand merupakan salah daerah yang dikuaisai Bani Ghaznawiyah, wilayah tersebut berada di Sijistan, India, dan Makran. Al-Maqdisi mengatakan bahwa daerah tersebut memiliki sumber daya yang berpotensi, contohnya perdagangan, bahan pertambangan, emas, dan SDA lainnya. Sebagian masyarakatnya ialah pedagang yang dikenal karena kejujuran. ${ }^{22}$ Di tahun 392 H/1002 M menguasai Kota Banjab di India selatan yang memperoleh Ghanimah ataupun harta rampasan peperangan yang kemudian diberikan ke Baitul Mal, Mahmud Ghazni pun mengimplementasikan wajib pajak untuk wilayah naungan Dinasti Ghaznawiyah. Penguasaan pada wilayah-wilayah yang subur dan kaya memberi pengaruh strategis untuk memajukan Dinasti Ghaznawiyah pada segi perekonomian. Retribusi pajak yang terkumpul berdasarkan semua wilayah yang ditaklukan beserta melimpahnya harta rampasan yang diperoleh dapat menghidupi sejumlah kegiatan ekonomi, sehingga dapat dinyatakan bahwa Dinasti tersebut adalah kerajaan yang sejahtera. Majunya dalam segi perekonomian memberikan pengaruh besar pada berkembangnya ilmu pengetahuan, peradaban, serta kebudayaan, salah satunya dalam segi kemiliteran.

c. Ilmu Pengetahuan dan Sastra

Perkembangan pada segi ilmu pengetahuan yang diraih Dinasti Ghaznawiyah yakni menjadi cikal akal terhadap peraturan Sultan Mahmud yang mendorong para sarjana agar berkarya serta tinggal pada daerah kepemimpiannya. Selain itu juga tidak sedikit yang ditempatkan di istana miliknya. Peraturan tersebut sangat hebat, sebab difasilitasi supaya dapat mengembangkan sastra dan ilmu pengetahuan. ${ }^{23}$ Sultan Mahmud Ghazni memberi pendanaan yang cukup besar. sekitar 400.000, ringgit emas yang setiap tahunnya diberikan pada kepentingan pendidikan, contohnya kaum terpelajar dan para penyair.

Sultan Mahmud Ghazni juga membentuk perguruan tinggi yang disebut Unsuri, selanjutnya ternyata dapat menghasilkan sarjana yang tidak sedikit pada sejumlah ilmu pengetahuan. Di abad ke-11 M, kesuksesan tersebut menjadikan nama Sultan Mahmud Ghazni jadi harum pada sejarahnya. Lahirnya penyair-penyair yang di masa kepemimpinan Sultan

Mahmud Ghazni menduduki wilayah strategis pada pelindung ilmu pengetahuan. Pimpinan Islam yang pernah mengajaknya dalam memajukan peradaban Islam di masa kepemimpinannya yakni terkenal adalah Biruni dan Firdaus.

1) Abu Al Karim Mansur Firdausi

Mahmud menyimpan arti dalam penyelidikan dengan detail mengenai sejarah purba Persia. Berdasarkan suatu rujukan, Mahmud memberi perintah agar meminta Firdausi datang untuk melaksanakan pekerjaan tersebut. ${ }^{24}$

\footnotetext{
${ }^{21}$ W. Montgomery Watt, Kejayaan Islam, terjemahan Kartono Hadikusumo (Yogjakarta: Tiara Wacana, 1990), hlm. 212.

${ }^{22}$ Ibid., hlm. 96.

${ }^{23}$ W. Montgomery Watt, Kejayaan Islam, hlm. 212.

${ }^{24}$ Ibid., hlm. 514.
} 
Al-Firdaus merupakan tokoh yang berpengaruh pada pembangkitan kembali sastra Persia. Dirinya merupakan penyair dari Tus yang karena didorong Mahmud Ghazni dan Bani Samani, melanjutkan sebuah epic poems in Persian yang terkenal dengan Syahnamah, yang sudah dibuat oleh penyair lainnya dengan nama Daqiqi yang tewas karena dibunuh. Syahnamah berisi cerita-cerita raja dimulai dengan legenda awal, salah satunya kerajaan Sasania. Dirinya juga mendukung dalam memajukan seni arsitektur maupun seni-seni lainnya. ${ }^{25}$

2) Abu al-Rayhan Muhammad bin Ahmad al-Biruni

Dengan mengembangkan wibawa istana yang ia pimpin, Mahmud Ghazni secara sengaja mengajak ilmuan dan para sarjana untuk mendatangi istananya. Mahmud Ghazni juga mengupayakan sejumlah hal dalam mengajak sarjana dan para ilmuwan ke daerah kekuasaannya. Ibnu Sina yang memperoleh undangan dengan nada yang mengancam supaya hadir dan meningkatkan ilmu di istana Ghaznawiyah. Meskipun kesannya terdapat paksaan. Al-Biruni menyukai eksistensinya di Ghaznawiyah. Pada tempat tersebut, dirinya dihormati dan secara bebas meningkatkan ilmu yang dimilikinya. Yang termasuk tugas Al-Biruni ialah menjadi astrolog istana untuk Mahmud Ghazni dan penggantinya.

d. Perkembangan Peradaban Islam pada Masa Dinasti Ghaznawiyah

Pada dunia Islam, tentunya banyak dijumpai sejarah-sejarah masa lalu pada masa keemasannya. Sebagaimana yang telah dipahami bahwa keberhasilan nabi Muhammad beserta sahabatnya, bahkan penerus setelahnya untuk mengembangkan Islam. Tidak hanya berkedudukan sebagai agama, namun Islam juga berperan sebagai pedoman hidup secara konkrit yang tidak hanya merujuk pada persoalan peribadatan, namun permasalahan militer, budaya, politik, serta perekonomian.

Perhatian mahmud Ghazni pada bidang ilmu pengetahuan cukup tinggi di masa kepemimpinanya (387-421 H/997-1030 M) hal tersebut bisa diketahui berdasarkan programprogam ilmiah antara lain :

1. Memprakarsai penulisan tafsir Al-Qur'an sesuai dengan ilmu Saraf ilmu Nahwu yang berdasarkan Hadits Sahih.

2. Mendirikan Madrasah yang besar sebagai lokasi pembelajaran.

3. Menghimbau seluruh filusuf Islam dan ulama sebagaimana Abu Nasr al-Arraq, Ibnu Sina, Al-Biruni, dan Ibnu Khamar Abu Sahl al-Masihi supaya bisa memetik manfaatnya berdasarkan pengetahuan yang dimiliki. ${ }^{26}$

Dalam sejarah tertulis bahwa cerita tentang seperti apa dirinya (Mahmud Ghazni) melakukan pembayaran 60.000 keping perak pada Firdausi sebagaimana yang sudah disepakati, begitu juga pada ilmuan yang lain. Tertulis juga di masa Mahmud dan puteranya Mas'ud, ilmuan lainnya contohnya Ibnu al-Khammar dan Ibnu al-Arraq, al-Baihaqi yang merupakan sejarawan, selanjutnya di zaman tersebut juga pada persoalan menerologi al-Biruni menuliskan buku dengan judul al-Jamahir fi al-Ma'rifat al-Jawahir (kompilasi pengetahuan mengenai batu permata).

\section{Kemunduran dan Keruntuhan Dinasti Ghaznawiyah}

1. Kemunduran Dinasti Ghaznawiyah

Mundurnya Dinasti Ghaznawiyah diawali ketika puteranya Muhammad ibn Mahmud Ghazni ditunjuk sebagai pengganti ayahnya yang telah meninggal di tahun 1030 M. Dirinya tidak disukai pasukan tentara, sehingga pada masanya Muhammad ibn Mahmud Ghazni dan Mas'ud ibn Mahmud (adiknya) berebut tahta. Nyatanya Mas'ud ibn Mahmud merupakan pimpinan yang tidak andal dan tidak dapat mencapai kesuksesan yang sudah diraih ayahnya,

${ }^{25} \mathrm{Ibid}$., hlm. 214.

${ }^{26}$ Ibid., hlm. 155. 
yakni Mahmud Ghazni. Penyerangan Bani Saljuk pada sejumlah provinsi Dinasti Ghaznawiyah memberi pengaruh siginikan pada Dinasti Ghaznawiyah saat berangkat di ambang kebinasannya. Situasi tersebut juga mengalami perselisihan antara sultan dengan dewan kesultanan memiliki pendapat yang berlawanan. Seluruh anggota dewan ingin supaya atensi pemerintah berfokus dalam menarik kembali daerah-daerah yang diambil Bani Saljuk dan daerah-daerah yang berusaha melepaskan dirinya. ${ }^{27}$

Mulai dari tahun 1040 hingga 1050 M peperangan selalu terjadi pada Bani Saljuk dan Dinasti Ghaznawiyah, namun lagi-lagi kedua pihak tersebut mengalami gencatan senjata sepanjang setengah abad. Di samping hal tersebut, Afghanistan juga mendapat pengakuan sebagai bagian daerah Ghaznawiyah. Selain menyerang Bani Saljuk kembali, Dinasti Ghaznawiyah juga harus menghadapi suku-suku Ghur dan Ghuzz, adapun suku tersebut dulunya sudah menjadi kekuatan besar untuk tentara Bani Saljuk, dengan demikian juga harus menyerang Bani Saljuk. Mobilitas dan kekuatan tentara suku tersebut memang dapat membuat kekuatan Ghaznawiyah pada wilayah Utara menjadi lumpuh. Selanjutnya munculnya suku Ghur sebagai kekuatan baru juga menginginkan daerah kedaulatan Dinasti Ghaznawiyah supaya semakin membuat Dinasti tersebut menjadi lemah. Hal tersebut menyebabkan kedudukan Lahore sebagai ibu kota kedua Ghaznawiyah menjadi semakin strategis untuk seluruh penguasa. ${ }^{28}$

Di tahun 1173 M, tentara Ghur merebut kota Ghazna dan menjadikan harus berpindah ke Lahore selanjutnya membuat menjadi pusat pemerintahan yang baru. Tetapi tentara Ghur juga merebut Lahore yang dinaungi Ibn Syam di tahun 1187 M, sehingga penguasanya yang paling akhir yakni Khasrav Malim juga dibunuh. Meskipun suku Ghur sudah menghancurkan Dinasti Ghaznawiyah tersebut, namun sebagai penguasaanya pada sebagian daerah anak benua India, tempat tersebut menjadi penentu masa depan Islam pada kawasan Asia Selatan. masyarakat Ghaznawiyah dapat membentuk pemerintah yang stabil dan populer sepanjang nyaris dua abad. ${ }^{29}$

Raja ke-3 Dinasti Ghaznawiyah di Iran, Mahmud Ghazni telah wafat di Tahun $421 \mathrm{H}$. Mahmud Ghazni pada tahun 387 mengambil alih kekuasaan saudaranya sendiri, Ismail. Raja Ghaznawiyah menaklukan raja-raja Ali Ziyar, Ali Buyeh, Samani, dan Shafari sehingga dapat menaklukan wilayah timur dan utara Iran. Dengan bertahap, daerah kedaulatan Ghaznawiyah semakin menjadi luas. Sehingga sesudah 34 tahun menjadi penguasa, Shah Ghaznawiyah wafat dikarenakan sakit. ${ }^{30}$

Muhamad Ibn Mahmud mengalami kenaikan tahkta dikarenakan amanat sang ayah, namun dirinya hanya bisa menguasai sepanjang lima bulan. Dirinya memiliki konflik pada Mas'ud Ibn Mahmud yang merupakan saudaranya sendiri, ia berikutnya terkenal dengan nama Mas'ud I. Konflik tersebut dialami dikarenakan terdapatnya penolakan dari Muhammad Ibn Mahmud atas permintaan saudaranya tersebut supaya diangkat menjadi gubernur pada wilayah Ishafan, Tubaristan, dan Jabal. Dikarenakan hal tersebut, tidak sedikit tentara yang berpihak kepada Mas'ud I karena dikenal sangat berani, selanjutnya Muhammad Ibn Mahmud dijatuhkan. ${ }^{31}$

2. Keruntuhan Dinasti Ghaznawiyah

Ditinjau berdasarkan sejarah Dinasti Ghaznawiah yang mengalami kemunduran dan kehancuran, maka bisa diketahui berdasarkan 2 hal, yakni :

\footnotetext{
${ }^{27}$ Muhammad Alim Ihsan, "Perkembangan Dakwah di Bidang Politik dan Ilmu Pengetahuan Pada Masa Dinasti Ghaznawi, Saljuk dan Buwaih", Jurnal Al Mishah, Volume 9 Nomor 2, Juli-Desember 2013: 293-310 (Palu: STAIN Datokarama Palu, 2013), hlm. 06.

${ }^{28}$ Ibid., hlm. 07.

${ }^{29}$ Philip K. Hitti, History of Arabs, hlm. 585.

${ }^{30}$ Ibid., hlm. 586.

${ }^{31}$ W. Montgomery Watt, Kejayaaan Islam, hlm. 213.
} 
a. Faktor Internal

Di tahun 115 M, ketika Mas'ud Ibn Ibrahim wafat dilanjutkan Sherzad ibn Mas'ud III, puteranya (11156-1116 M), tetapi hanya sekali dirinya memerintah, lalu diganti Malik Arslan ibn Mas'ud III, saudaranya (1116-1118 M), kemudian sesudah masa pemerintahan Malik Arslan ibn Mas'ud selama 2 tahun, dengan demikian diganti Bahram Shah, saudaranya (1118-1157 M). Karena keseringan dalam mengganti raja, hal tersebut mengalami ketidakstabilan yang mengakibatkan pemerintahan Dinasti Ghaznawiyah menjadi lemah. ${ }^{32}$ Sering digantinya raja tersebut dikarenakan tidak terdapatnya kepandaian ataupun kemampuan untuk menjadi pemimpin diantara keluarganya tersebut, salah satunya karena sangat serakah pada kekuasaannya, sehingga pasukan militernya juga ikut serta mempengaruhinya kemudian menimbulkan konflik pada Dinasti tersebut.

b. Faktor Eksternal

Pada masa pemerintahan Bahram Shah, pihak dinasti Saljuk, yakni Sanjar melakukan penyerangan terhadap Dinasti Ghaznawiyah dan mengambil aset negaranya. Sehingga Dinasti Saljuk dapat dikuasai Bahram Shah mengakui kekuasaan dinasti Saljuk yang membantunya untuk mencegah penyerangan saudaranya sendiri, yakni Malik Arslan ibn Mas'ud III. Dengan dibantu Sanjar, Bahram Shah juga dapat memusnahkan penyerangan dinasti Ghuriyah oleh 'Ala al-din (Jahansuz) dimulai dengan memusnahkan Ghazna di ujung tahun $1150 \mathrm{M} \cdot{ }^{33}$ Walaupun Bahram Shah sudah sejak dulu memerintah, tapi dia tidak cukup kuat melaksanakan pemerintahan.

\section{Perkembangan Dinasti Ghaznawiyah Pada Masa Pemerintahan Mahmud Ghazni}

Sistem Pemerintahan Dinasti Ghaznawiyah pada Masa Pemerintahan Mahmud Ghazni

Mahmud Ghazni ialah putera Sabuktaqin yang tertua dan lahir di tahun 358 H/969 M. sang ayah ditunjuk Raja Nuh II dari Bukhara yang merupakan Gubernur pada wilayah Khurasan dan dipercayai untuk memegang jabatan sebagai wakil. Dari kaum Ismail, Mahmud Ghazni mengambil alih Neshapur untuk dijadikan ibukota wilayahnya saat sang ayah wafat pada 387 H/997 M. dari tangan sang saudara, Mahmud Ghazni berhasil mengambil Ghazna lalu di tahun 389 H/999 M mengalami kenaikan tahta. ${ }^{34}$

Harus diketahui Mahmud Ghazni memusnahkan kota ataupun daerah yang ditaklukkanya secara merata. Walaupun terdapat kebanggan tersendiri terkenal dengan sebutan penghancur berhala, dirinya tidak pernah mengenal pembunuhan massal. Penyerangan oleh pasukan Mahmud Ghazni membuat raja-raja Hindu di India menjadi ketakutan, di antaranya Raja Hadarata yang memutuskan untuk menganut agama Islam dengan lebih kurang 10.000 orang pengikut di tahun $411 \mathrm{H} / 1020 \mathrm{M}^{35}$

Pada masa pemerintahan Mahmud Ghazni, dalam sektor politik sampai pada masa kejayaannya. Ghazna yang dulunya merupakan kerajaan kecil dan memiliki banyak bangunan runtuh karena peperangan, maka dibangun kembali menjadi wilayah perkotaan besar yang dapat dijadikan pusat mengembangkan ilmu pengetahuan maupun budaya. Wilayah itu lebih luas dimulai dengan sungai Ozus di Amudarya (Asia Tengah) hingga sungai Indus (pesisir selatan India), dimulai dari pinggiran laut Kaspia di utara sampai dengan India tepatnya di sungai Gangga. ${ }^{36}$

\footnotetext{
32 Ira M. Lapidus, Sejarah Sosial Umat Islam, terjemahan Ghufron A. Mas'adi (Jakarta: PT. Raja Grafindo Persada, 2000), hlm. 270.

${ }^{33}$ Hasan Ibrahim Hasan, Sejarah dan Kebudayaan Islam, hlm. 101

${ }^{34}$ Jamil Ahmad, Seratus Muslim Terkemuka (Jakarta: Pustaka Firdaus, 1984), hlm. 392

${ }^{35}$ Dewan Redaksi Ensiklopedi Islam, Ensiklopedi Islam Cet. II (Jakarta:PT. Ichtiar Baru Van Hoeve, 1994), hlm. 155.

${ }^{36}$ W. Montgomery Watt, Kejayaan Islam, terj. Kartono Hadikusumo (Yogyakarta: Tiara Wacana, 1990), hlm. 212
} 


\section{Perkembangan Dinasti Ghaznawiyah pada Masa Pemerintahan Mahmud Ghazni}

Kepemimpinan Dinasti Ghaznawiyah mencapai puncak keemasan di masa kepemimpinan Mahmud Ghazni yang menjabat kurang lebih 34 tahun. Kekuatannya bisa digunakan dalam melakukan ekspansi daerah kekuasaannya sampai ke wilayah India, hingga mampu menguasai Bathinda, Peshawar, Baluchistan tahun 402-403 H/1011-1012 M, n Kashmir di tahun 391-394 H/1001-1004 M, Delhi tahun 405-406 H/1014-1015 M, Kangra tahun 1009, dan Punjab ditaklukan di tahun 1006 M. Daerah yang luas serta kaya akan sumber daya alamnya menjadikan perekonomian kerajaan tersebut meningkat, sehingga bisa digunakan untuk membuat masyarakatnya sejahtera.

Dinasti Ghaznawiyah berkembang pesat di masa kepemimpinan Sultan Mahmûd Ghazni berdasarkan sejumlah bidang, yakni :

1. Perkembangan Bidang Politik

Pada masa kepemimpinan Mahmud Ghazni, dalam sektor politiknya sampai pada masa kejayaannya. Dinasti Ghaznawiyah yang dulunya merupakan kerajaan kecil dan memiliki banyak bangunan runtuh karena peperangan, maka dibangun kembali menjadi wilayah perkotaan besar yang nanti dapat dijadikan pusat pengembangan ilmu pengetahuan maupun budaya. Wilayah itu lebih luas dimulai dengan sungai Ozus di Amudarya (Asia Tengah) hingga pesisir selatan India (sungai Indus), dimulai dari pinggiran laut Kaspia di utara sampai dengan India tepatnya di sungai Gangga.

Dimulai tahun $1009 \mathrm{M}$, Mahmud ghazni dengan atensinya fokus terhadap penaklukkan anak benua India, yakni Somnat, lokasi pemujaan umat Hindu pada daerah Khatiawar (Gujarat). Di Somnat, Mahmud Ghazni menghancurkan kerajaan Gurajat beserta Pagodanya yang biasa dikenal karena sangat indah, sehingga Mahmud Ghazni diberi gelar sebagai "The Idel Breaker" (penghancur berhala). Sangat bernilai sekali kuil suci tersebut untuk umat Hindu, bahkan dibutuhkan sejumlah 2000 orang Brahmin untuk mengurusnya. Berikutnya Mahmud Ghazni menggantikan agama Brahmana menjadi Islam.

2. Perkembangan Bidang Ekonomi

Wilayah penaklukkan Dinasti Ghaznawiyah salah satunya ialah Khurasan yang telah membawa beberapa perkembangan di sektor perekonomian. Pentingnya Khurasan bagi Mahmud Ghazni dikarenakan kejayaan serta kemakmuran yang didapatkan berdasarkan pungutan pajak sehingga cukup mudah untuk menaklukkan India. Dalam menaklukkan daerah India dilaksanakan sesudah selesainya pembersihan pada wilayah Khurasan. Tertapi harus diketahui bahwa dalam menaklukkan anak benua India tidak hanya pada perbatasannya yang cenderung diakibatkan dari tindakan Raja Anandapal, penguasa Batinda yang merupakan putera Raja Jaipal. Saat Mahmud Ghazni tengah menaklukan daerah Khurasan, Raja Anandapal mengambil daerah Peswar dan Punjab yang umumnya merupakan daerah kedaulatan Ghazna semenjak gubernur Sebuktaqin. Peristiwa tersebut menarik perhatian Mahmud dalam mengerahkan tenaganya pada daerah tersebut.

Dinasti Ghaznawiyah berkembang dalam menutupi masa sekarang dari Ghazni, barat laut India, Pakistan, Afganistan, dan Iran yang dijalankan melalui penyebaran Islam pada benua India, pengumpulan kekayaannya diperoleh berdasarkan penguasan kota di India, penghargaan yang diberikan India mengharuskan raja-raja dinasti Ghazni juga diberi keuntungan pada posisinya selaku penghubung perdagangan Mediterania dengan Cina.

3. Perkembangan Ilmu Pengetahuan

Peradaban Islam memang berperan penting pada dunia, membawa banyak manusia dari dunia kebinasaan akhlak, penyimpangan, kebodohan, dan kegelapan yang kemudian diberikan nilai agar dapat memahami dunia sebelum Islam memiliki bermacam ikatan. Peradaban Islam 
berdasarkan Al hadis dan Al qur'an, kedua landasan tersebut tidak membedakan agama, bentuk, dan jenis. Kedua hal itu menjadi dasar pembentukan peradaban Islam. ${ }^{37}$

Berbagai fasilitas belajar dan mengajar dibangun oleh Mahmud Ghazni sehingga memunculkan sastrawan dan ilmuwan handal, antara lain:

a. Abu Al-Nashr Muhammad bin Abd Al-Jabbar Al-Utbi. Dirinya merupakan ahli sejarah dan sastrawan terkenal, yang termasuk kitab karyanya yang termansyur yakni Al-Yamani, yang mana dinisbahkan pada gelar Sultan Mahmud Ghazni (Yamin al-Daulah). Kitab tersebut memuat sejarah bani Ghaznawiyah dan dan sejumlah perkembangan yang diraih di zaman kepemimpinan Mahmud Ghazni

b. Abu Al-Fath Al-Busti. Selain merupakan penyair, dirinya juga merupakan penasehat hukum dan sekretaris pribadi Mahmud Ghazni. Dirinya merupakan penyair besar, tulisannya memiliki arti tersirat sehingga tidak mudah dipahami artinya kecuali seseorang yang memiliki keahlian pada segi kebahasaan.

c. Abu Al-Qasim bin Hasan Al-Maimanda. Di samping merupakan penyair, dirinya juga merupakan menteri kepercayaan Mahmud Ghazni. Dirinya dikenal sebagai sastrawan cakap dan memiliki wawasan luas, ahli pada peperangan, dan mempunyai cita-cita yang tinggi.

d. Abu Mansur Al-Tsa'alabi. Abu Mansur Al-Tsa'alabi penyair yang suka menuliskan syair dengan isi pujian untuk Mahmud Ghazni.

e. Badi' Al-Zaman Al-Hamdani. Badi' Al-Zaman Al-Hamdani sastrawan yang sangat populer di zamannya. Dirinya sudah menuliskan 16 bait Syair dengan isi pujian untuk Mahmud Ghazni. ${ }^{38}$

Abu Al-Rayhan Muhammad bin Ahmad Al-Bairuni (973) M. dilahirkan pada kota Kath, ibukota Khwarizm wilayah amu darya bagian selatan pantai laut Aral. Abu Al-Rayhan Muhammad bin Ahmad Al-Bairuni merupakan keturunan iran dan pernah belajar dari Abu Nasr Mansur bin Irak Jilani yang merupakan ahli matematika. Dirinya merupakan sarjana pertama yang mampu memperoleh sejumlah ilmu pengetahuan dan menulis sejumlah kitab yakni:

a. Menuliskan kitab abstraksi tentang Astrologi, Aritmatika, Astronomi, dan dalam kitab Tafhim, Li Awa'il Sina'at At-Tanjim.

b. Ulama dan Ahli di bidang bahasa, kronolohi, geografi, sejarah, fisika, farmasis, kedokteran, dan pengamat kebudayaan.

c. Menulis kitab Al Jamahir Fi Ma'rifat Al-Jawahir, kisah tentang minerologi yang dituliskan di zaman sultan maudud bin mas'ud

d. Menuliskan kitab yang menjadi karyanya yang utama al-qanun al-mas'udi fi al-haya wa an-nujum, ensiklopedia astronomi paling lengkap di bidang astrologi, geografi, astronomi, dan sejumlah matematika Persia, Babilonia, India, dan Greek.

e. Menuliskan Kitab Tarikh Al-Hind pada perjalanan militer ke India.

f. Pada segi astronomi, dirinya mendapati arah kiblat sholat dengan tepat.

g. Menentukan dasar ilmu-ilmu sudut.

h. Menentukan bahwasannya ketiga sudut segitiga besarnya 180 derajat.

i. Bumi berotasi dengan mengelilingi matahari 600 tahun sebelum Galileo.

4. Perkembangan di Bidang Pembangunan

Dalam segi seni arsitektur, perkembangannya bisa dilihat dari megahnya arsitektur menara maupun istana Dinasti Ghaznawiyah. Bangunan-bangunan tersebut mempunyai kadar seni yang tinggi. Realitas tersebut merupakan alasan paling tepat bahwa atensi negara pada

\footnotetext{
${ }^{37}$ Raghib al-Sirjani, Sumbangan Peradaban Islam pada Dunia (Jakarta: Pustaka al-Kautsar, 2011), hlm. 17

${ }^{38}$ Jamil Ahmad, Seratus Muslim Terkemuka, hlm. 224
} 
berkembangnya bidang ilmu pengetahuan, agama, ataupun peradaban yang cukup besar. Hingga sekarang, bangun tersebut masih bisa disaksikan.

Sangat disayangkan di tahun 1258 H/1842 M, Inggris memindahkan pintu menara mesjid pada makam istana raja di India dan Kota Ghazna itu, sebab orang-orang tersebut berasumsi bahwa barang itu menjadi komponen terhadap Pagoda/Candi di Somnat yang dulunya dimusnahkan Mahmud Ghazni. ${ }^{39}$ Di sampingnya didirikan tempat peristirahatan Sultan. Di masa kepemimpinan Mahmud Ghazni, didirikan madrasah yang banyak menghasilkan para ulama dan ilmuan. Mahmud Ghazni mendirikan Dinasti Ghaznawiyah dan merupakan Ibukota yang hebat, dengan julukan "Permaisuri Timur". Masjid Agung Ghaznawiyah terkenal sebagai "Pengantin Surga" dan menjadi keajaiban dunia Timur di masanya. Di samping hal tersebut Mahmud Ghazni mewarnai ibukota tersebut dengan mendirikan tempat penampungan air yang kokoh, talang-talang air, waduk, pendopo-pendopo, masjid-mesjid yang indah, perguruan tinggi, perpustakaan, dan museum. ${ }^{40}$

Di antara hasil pekerjaan secara umum, masih terdapat parti-parit yang hingga saat ini bisa dimanfaatkan. Parit-parit tersebut didirikan di mulut suatu celah, 25 kaki di atas permukaan air sungai Nawa, memiliki jarak 18 mil dari Ghazni, panjang parit itu 200 yard (sekitar 182, 88 meter $)^{41}$

\section{STRATEGI MAHMUD GHAZNI DALAM MEMAJUKAN PERADABAN ISLAM}

Penguasa pertama di sejarah dunia dengan gelar sultan secara resmi yaitu penguasa Dinasti Ghaznawiyah, Sultan Mahmud Ghazni. Penyematan gelar tersebut kepada Mahmud Ghazni yang berarti dia adalah seorang Khalifah Muslim, pemimpin paling tinggi dalam otoritas keagamaan, dan pemimpin politik dari wilayah kekuasaan sangat luas, sekarang disebut dengan negara Iran, Uzbekistan, Turkmenistan, Afghanistan, Kyrgyzstan, India utara dan Pakistan.

Kemudian, tanggal 2 November 971 M Yamin ad-Dawlah Abdul-Qasim Mahmud ibn Sabuktegin atau terkenal sebagai Mahmud Ghazni lahir di kota Ghazna (sekarang dinamakan Ghazni) di Afghanistan tenggara. Sementara, ayahnya yaitu Abu Mansur Sabukteqin ialah orang Turki, Sabuteqin merupakan seorang prajurit Mamluk yang berasal dari Ghazni.

Pada waktu Dinasti Samanid mulai runtuh, Sabukteqin berusaha untuk menguasai kota Ghazni tahun 977 M. Kemudian, mulai penaklukkan kota-kota besar Afghanistan lainnya seperti Kandahar. Kerajaan tersebut merupakan inti dari Kerajaan Ghaznawiyah. Selanjutya, Sabukteqin diberikan kepercayaan mendirikan Dinasti Ghaznawiyah. Sementara itu Mahmud Ghazni memiliki dua orang adik lelaki, salah satunya adalah Ismail. Ismail merupakan anak dari isteri pertama Sabukteqin. Sehingga ibu Ismail merupakan wanita yang dilahirkan bebas dari darah mulia akan menjadi kunci dalam persoalan penggantian ketika Sabukteqin meninggal tahun 997 M.

Mahmud Ghazni dalam memajukan peradaban Islam di India, melakukan beberapa strategi untuk dapat mencapai masa kejayaan serta kemajuan Islam. Adapun strategi yang dilakukan Mahmud Ghazni untuk memajukan peradaban Islam di India sebagai berikut.

\section{Kebijakan Politik dan Pemerintahan}

Pesatnya perkembangan peradaban sejak kesultanan mahmud Ghazni, seiring semakin banyaknya para ulama, ilmuwan, sufi dan para ahli diberbagai bidang masuk ke India. Terjadinya pertukaran budaya yang saling menguntungkan pihak Islam maupun India, memunculkan peradaban baru sebagai hasil perpaduan kedua budaya yaitu bahasa baru. Islam yang datang di India tidak berdasarkan kekerasan, namun sebagai kebutuhan masyarakat ketika itu. Penyebaran

\footnotetext{
${ }^{39}$ W. Montgomery Watt, Kejayaan Islam: Kajian Kritis dari Tokoh Orientalis, hlm. 21

${ }^{40}$ Busman Edyar, Sejarah Peradaban Islam, hlm. 96

${ }^{41}$ Jamil Ahmad, Seratus Muslim Terkemuka, hlm. 394-395
} 
Islam yang dikatakan berhasil di India dikarenakan banyak faktor namun yang utama ialah karena solidaritas yang sejati, kuatnya rasa persaudaraan serta penegakkan keadilan. Administrasi dan pranata sosial dibangun dari peradaban Islam secara baik. Peradaban Islam dan India terhubung, saling memberi dan menerima pada berbagai bidang ilmu pengetahuan, sosial, politik, budaya dan ekonomi. Pengaruh Islam di India sangat besar di berbagai bidang di antaranya dari pelarangan adat Sati Daho hingga akhirnya secara resmi dilarang. Islam masih bertahan di India walaupun hanya minoritas. Akan tetapi, di beberapa wilayah India Utara, Islam masih menjadi mayoritas. Pembentukan negara Islam oleh Pakistan dan Bangladesh juga menjadi Negara Islam bahkan Islam sebagai agama resmi.

Abad pembangunan daualah Islamiyah pada abad ke-10 dimana dunia Islam dimulai dari Cordova di Spanyol hingga Kemultan di Pakistan, terjadinya pembangunan diberbagai bidang, utamanya pada ilmu pengetahuan, seni dan teknologi. Dunia Islam ketika itu dalam kondisi jaya, makmur dan maju; sebaliknya dunia Barat masih dalam kondisi bodoh, primitif dan gelap.

Peradaban yang maju pada suatu zaman tidak terlepas dari berdirinya dinasti ketika itu. Seperti diketahui pada masa kekuasaan Bani Abbas sudah membawa peradaban Islam hingga puncakanya, dimulai kajian ilmu sejak Bani Umayyah sebagai upaya paling kuat ketika periode Bani Abbasiyah. ${ }^{42}$

Dalam kondisi militer dan politik mengalami penurunan pada waktu itu, hal lainnya dengan ilmu pengetahuan yang mulai mengalami kemajuan pesat. Hal tersebut dikarenakan setiap kerajaan, setiap Amir, atau Sultan atau khalifah berlomba memajukan ilmu pengetahuan, berlomba mendirikan perpustakaan, mengumpulkan para pengarang, ilmuwan, penerjemah dan memberi kedudukan terhormat untuk pujangga dan ulama.

Dampak kebijakan pemerintah pusat di Baghdad dengan sangat memperhatikan kemajuan ilmu pengetahuan dari pada melakukan kontrol wilayah kekuasaan yang semakin luas berakibat pada kestabilan politik di sebuah Provinsi yang dipegang gubernur berupaya dalam memisahkan diri dan mendeklarasikan kekuatan baru yang mampu bersaing dengan pemerintah pusat.

Sejak munculnya pemerintahan dari Islam di Multan dan Sind serta India secara menyeluruh, penduduk Arab yang melakukan urbanisasi tidak bisa lagi terbendung. Orang Arab banyak yang menetap dan menjadi satu komunitas. Sehingga terjadilah akulturasi, asimilasi, dan transfer budaya antara Arab Islam dengan warga India. Abdul Karim menyebutkan terjadinya jalur asimilasi global di bidang ilmu pengetahuan, bangunan dan seni, ilmu pengetahuan serta bahasa. ${ }^{43}$

Terjalinnya hubungan Islam dengan India dalam bidang ilmu pengetahuan secara baik dan terjadi pertukaran budaya. Banyak penerjemahan buku India ke dalam bahasa Arab di abad ke-8 M. Ketika itu dikirim ke India para ilmuwan Arab untuk belajar berbagai ilmu di India. Sedangkan berbagai ilmuwan India diundang ke Baghdad agar para ilmuwan Arab mengenal berbagai ilmu yang ada di India seperti dari keterangan Amir Khusru bahwa ahli astronomi Arab, Abu Mashar, belajar di Benaras, pusat kebudayaan Hindu. Abu Yazid al-Bustami selama sepuluh tahun juga pernah tinggal di Sind dan berguru kepada penduduk pribumi.

Mahmud Ghazni ialah penguasa Islam yang sangat memiliki pengaruh dan dari keperkasaannya di medan perang dimana Mahmud Ghazni selalu menang dari lawan-lawannya dengan demikian khalifah al-Qadir Billah memberi gelar "Amin addaulah" (kepercayaan hormat terhadap ulama dan ilmu) dan "Yamin addaulah" (tangan kanan pemerintah). Mahmud Ghazni mempunyai 2 anak, yaitu Mas'ud dan Muhammad. Mahmud Ghazni memberi wasiat yang berkuasa sesudah dirinya yaitu anak bungsu (Muhammad). Kebijakan tersebut memunculkan

\footnotetext{
${ }^{42}$ Nunzairina, "Dinasti Abbasiyah: Kemajuan Peradaban Islam, Pendidikan dan Kebangkitan Kaum Intelektual”, Jurnal Sejarah Peradaban Islam (Medan: Program Studi Peradaban Islam, Fakultas Ilmu Sosial, UIN Sumatera Utara, 2020) Volume 3 Nomor 2, 93-103.

${ }^{43}$ Ahmad Faidi, "Akulturasi Budaya Islam dan India: Tinjauan Historis pada Dialektika Kebudayaan Islam di India”, Journal of History and Cultural Hiritage (Salatiga: Mahesa Research Center, 2020), Volume 1 (2), 46-54.
} 
pertikaian antara dua orang bersaudara. Selanjutnya, pemerintahan Dinasti Ghaznawiyah melemah hingga akhirnya dihancurkan oleh bangsa Saljuk dan Ghauri.

Keberhasilan Mahmud Ghazni didukung berbagai faktor. Keadaan masyarakat Hindu India yang lebih banyak secara kuantitas, namun mereka tidak memiliki rasa persatuan. Orang Hindu masih menganut taktik perang kuno dengan hanya mengandalkan gajah. Sedangkan, pasukan Islam mmepunyai konsep disiplin, organisasi dan persatuan lebih baik. Hal tersebut semakin dikuatkan melalui kepemimpinan Mahmud Ghazni yang diplomatis dan taktis. Walaupun sudah melakukan penaklukkan diberbagai wilayah di India, Mahmud Ghazni tidak menancapkan kekuasaannya pada berbagai wilayah penaklukkannya tersebut terkecuali Punjab. Ada perbedaan pendapat dari para sejarawan tentang motif penaklukkan Mahmud Ghazni. Sebagian memperlihatkan pada motif ekonomi dan politik, akan tetapi motif utama adalah agama. Disebabkan ekspedisi secara terus menerus, hampir semua wilayah India utara jatuh ke tangan Mahmud Ghazni. Berbagai ekspedisi tersebut secara politis membuka jalan untuk penaklukkan India di masa depan oleh pasukan Islam. ${ }^{44}$

Mahmud Ghazni selalu memberi sarana prasarana serta imbalan menarik untuk ulama, para pengajar dan cendikiawan supaya selalu berkarya di wilayah Ghazna, ia membangun gedung untuk aktivitas belajar mengajar dari tingkat dasar hingga perguruan tinggi. Mahmud Ghazni memberikan anggaran besar terhadap aktivitas sektor pendidikan.

Keberhasilan Dinasti Ghaznawiyah untuk memperluas wilayah kekuasaannya ke sejumlah wilayah. Seluruh perluasan tersebut tidak terlepas dari upaya serta peranan dari penguasa Dinasti Ghaznawiyah dalam memberikan kekuatan politiknya yaitu melalui perluasan wilayah kekuasaannya ke seluruh India. Sementara itu, Mahmud Ghazni sudah melakukan penyerangan dalam waktu sekitar 26 tahun (tahun 391-417 H/1000-1026 M) sebanyak 17 kali. $^{45}$

Mahmud Ghazni menaklukan wilayah tidak pernah melakukan pembunuhan massal, Mahmud Ghazni hanya disebut sebagai penghancur berhala. Sehingga dari serangan pasukan Mahmud Ghazni memunculkan ketakutan pada raja-raja Hindu di India yaitu raja Hadarata dengan berakhir untuk memeluk agama Islam beserta sekitar sepuluh ribu orang pengikutnya pada tahun $411 \mathrm{H} / 1020 \mathrm{M}^{46}$

Mahmud Ghazni pada masa kekuasaanya peradaban mengalami kemajuan pada bidang politik. Semula Dinasti Ghaznawiyah merupakan kerajaan kecil, yang masih banyak reruntuhan bangunan dampak dari peperangan, ia membangun lagi supaya menjadi kota megah yang nantinya menjadi pusat perkembangan dan kebudayaan ilmu pengetahuan. Dinasti tersebut kemudian lambat laun meluas wilayahnya, dari utara pinggiran laut Kaspia sampai dengan di India tepatnya di sungai Gangga, dari sungai Ozus di Amudarya (Asia Tengah) hingga pesisir selatan India (sungai Indus). ${ }^{47}$

Fokus yang besar terhadap ilmu pengetahuan selama masa pemerintahan $(387-421 \mathrm{H} / 997$ - $1030 \mathrm{M}$ ) bisa diketahui dari beberapa aktivitas-aktivitas ilmiah antara lain: ${ }^{48}$

a. Mempelopori penulisan tafsir Al-qur'an sesuai ilmu Nahwu dan ilmu Saraf dan berpedoman pada Hadits Sahih.

b. Mendirikan Madrasah untuk kegiatan belajar.

c. Memberi anjuran untuk banyak ulama dan filusuf Islam seperti Al-Biruni, Ibnu Sina, Abu Nasr al-Arraq dan Ibnu Khamar Abu Sahl al-Masihi supaya bisa diambil manfaat dari ilmu yang dimiliki.

\footnotetext{
${ }^{44}$ Jamil Ahmad, Seratus Muslim Terkemuka (Jakarta: Pustaka Firdaus, 1984), hlm. 399.

${ }^{45}$ Busman Edyar, Sejarah Perdaban Islam (Jakarta: Pustaka Asatruss, 2009), hlm. 95.

${ }^{46}$ Dewan Redaksi Ensiklopedi Islam, Ensiklopedi Islam Cet. II ( Jakarta: PT. Ichtiar Baru Van Hoeve, 1994 ), hlm. 155.

${ }^{47}$ W. Montgomery Watt, Kejayaan Islam, terjemahan Kartono Hadikusumo (Yogyakarta: Tiara Wacana, 1990), hlm. 212.

${ }^{48}$ Dewan Redaksi, Ensiklopedi Islam Cet. 2, ( Jakarta: PT. Ichtiar Baru Van Hoeve, 1994 ), hal. 155
} 
Penguasa Dinasti Ghaznawiyah yang memberikan perhatian khusus dari Mahmud Ghazni untuk perkembangan peradaban dan ilmu pengetahuan terlihat dari usaha secara konkret melalui pembangunan berbagai gedung sekolah dan lembaga lembaga pendidikan lainnya, dengan demikian kota Ghazna menjadi pusat pengkajian ilmu pengetahuan yang dikunjungi banyak ilmuan.

Mahmud Ghazni juga melakukan pembangunan pada sektor pendidikan yaitu perguruan tinggi dengan pemberian nama yaitu Insani, bahkan mampu mencetak banyak sarjana pada berbagai disiplin ilmu pengetahuan. Nama Mahmud Ghazni menjadi harum karena keberhasilan tersebut dalam sejarah perkembangan ilmu pengetahuan abad ke-11 M. Beberapa penyair yang lahir ketika pemerintahan Mahmud Ghazni antara lain As'adi Thûsiy, guru dari al-Firdawsi, sastrawan tersebut mempunyai berbgaai karya. Syah-mana dan al-Farukhi berkarya dan menetap di Ghazna. Ilmuwan lainnya yang terkenal yaitu Rayhan Muhammad al-Biruni (973-1048 M), yang sudah menulis berbagai kitab di berbagai disiplin ilmu pengetahuan, seperti Matematika, Ilmu Alam, Sejarah, Astronomi dan lainnya. Karyanya yang termasyur ialah Tahqîq fî al-Hind (penelitian di India).

Pencapaian kemajuan dari Dinasti Ghaznawiyah, utamanya dibawah pemerintahan Mahmud Ghazni terlihat dari berbagai aspek. Ketika masa Sabuktiqin, perluasan wilayah Dinasti Ghaznawiyah melalui penaklukkan beberapa wilayah di Kusdar dan Sijistan. Selain itu kemampuan dalam mempertahankan Iran bagian barat dan Transoxania dari serbuan Bani Saljuk.

Kemajuan bidang politik pada masa pemerintahan Mahmud Ghazni. Semula Ghazna merupakan kerajaan kecil, yang masih banyak reruntuhan bangunan dampak dari peperangan, pembangunan kembali menjadi kota megah sebagai pusat perkembangan dan kebudayaan ilmu pengetahuan. Meluasnya kerajaan tersebut dari pinggiran laut Kaspia di utara sampai dengan India tepatnya di sungai Gangga, dari sungai Ozus di Amudarya (Asia Tengah) hingga pesisir selatan India (sungai Indus). ${ }^{49}$

\section{Kebijakan Militer}

Tentara berkebangsaan Turki yang mendominasi pemerintahan dinasti Samani mempunyai pengaruh besar pada politik Dinasti Ghaznawiyah. Keberanian dan profesionalitas dalam peperangan menjadikan penguasa Samaniyah bergantung pada keahlian mereka. Kebutuhan terhadap angkatan perang yang handal menjadi keharusan untuk menjaga wilayah yang sedemikan luas. Sehingga dampaknya berupa tentara yang dahulunya merupakan budak-budak tersebut mampu menempati berbagai posisi penting di lingkungan istana, apalagi pada posisi panglima angkatan perang yang dapat diduduki. Seperti Alpataqin, panglima perang masa pemerintahan sultan Abdul Malik bin Mansur. ${ }^{50}$

Pada abad ke-11 M tahun 396 H/1005 M dalam misi penaklukkannya, raja-raja Punjab dan Hindu serta daerah Sind mudah untuk dikalahkan, selanjutnya melakukan penyerangan pada tahun 400 H/ 1009 M ke Nagarakot, tahun 405 H/1014 M ke Negeri Dawab kemudian melakukan penaklukkan dataran tinggi Khasmir, perluasan wilayah hingga ke Transoxania, Bukhara dan terakhir menanklukkan wilayah Isfahan dan Ray. Selama peperangan 34 tahun sangat perkasa bahkan dalam pemerintahannya menjadikan sebuah keberhasilan dalam pengembangan kekuasaan Islam hingga ke India. Mengetahui keperkasaan dan kemajuan tentara Mahmud Ghazni tersebut, kemudian maharaja - maharaja India mengadakan persekutuan $(415 \mathrm{H} / 1024 \mathrm{M})$ untuk melawan Mahmud Ghazni dengan tentaranya. Namun sebelum ada penyerangan, Mahmud Ghazni terlebih dahulu menyerang dan menaklukkan Lahgore sehingga tidak ada lagi pembatas antara benua India

\footnotetext{
${ }^{49}$ Sadari, "Asimilasi Spektrum Peradaban Islam dan Keberislaman di India", Misykat, Volume 05, Nomor 01, 2020.

${ }^{50}$ Abu Haif, Eksistensi Mamluk dalam Membangun Perdaban Islam pada Abad Kegelapan (Makassar: Alauddin University PRESS, 2012 ), hlm. 10.
} 
secara menyeluruh. Setelah itu dilakukan penyerangan ke Kawaliur dan Kaligar, bahkan maharaja kedua negeri tersebut wajib membayar Upeti (Jaziah) ke Mahmud Ghazni setiap tahun. ${ }^{51}$

Mahmud Ghazni ketika berusia 55 tahun pada tahun 1026 M, bergerak melakukan penyerangan ke negara bagian Kathiawar, letaknya di pantai barat India (Laut Arab). Pergerakan pasukannya menuju ke ujung selatan Somnath, yang terkenal dengan kuil indah Dewa Siwa.

Perluasan wilayah kekuasaan dan perkembangan bidang Ilmu Pengetahuan berhasil dalam kurung waktu 26 tahun oleh Mahmud Ghazni dari masa pemerintahannya (387-421 H/ 997$1030 \mathrm{M})$. Hal ini didukung beberapa faktor diantaranya:

1. Letak yang srategis dari Kota Ghazna ditempati oleh Mahmud Ghazni dan para pendukungnya sebagai ibu kota dinasti dan selalu bergerak mengekspansi secara militer.

2. Mempunyai semangat dalam keagamaan dan jihad, menurut Mahmud Ghazni dengan berperang merupakan jalan dakwah Islam terhadap orang-orang penyembah berhala dan orang kafir.

3. Harapan dan keinginan mendapatkan rampasan perang untuk membangun dan memajukan perekonomian, dikarenakan pada masa itu raja-raja Hindu sangat kaya dengan harta.

Selain dari faktor Mahmud Ghazni selain terkenal handal dalam memimpin perang, keungggulan Ghaznawiyah didukung faktor situasi politik di beberapa penaklukkan daerah. Mahmud Ghazni diuntungkan dengan kondisi India yang terpecah tidak ada persatuan sehingga mudah untuk ditaklukkan. Hal yang sama juga terjadi pada penaklukkan Raja Jaipul ketika masa pemerintahan Sebuktigin.

\section{Kebijakan Ekonomi}

Kejayaan pemerintahan Dinasti Ghaznawiyah ketika masa pemerintahan Mahmud Ghazni yang berkuasa selama 34 tahun. Wilayah kekuasaan semakin diperluas dengan kekuatan yang dimiliki hingga mencapai wilayah India, bahkan pada tahun 391-394 H/1001-1004 M mampu menaklukan Kashmir, Peshawar dan Bathinda, pada tahun 1006 M menguasai Punjab, pada tahun 1009 M menguasai Kangra, pada tahun 402-403 H/1011-1012 M menguasai Baluchistan, selanjutnya pada tahun 405-406 H/1014-1015 M menguasai Delhi. Perkonomian negeri ini menjadi sangat kuat dengan melimpahnya sumber kekayaan dan wilayah yang luas, sehingga bisa dimanfaatkan untuk memakmurkan negeri.

Seperti di tulis dalam bukunya M. Nazim menyatakan bahwa "Revenue is usually collected in cash, but it also allows payments in kind. The large quantities of sheep and the large quantities of grain collected were stocked for the use of the Sultan while traveling through the empire, or distributed to sufferers in times of famine. ${ }^{52}$

Pendapatan tersebut biasanya dikumpulkan dalam berupa tunai akan tetapi dalam pembayaran berupa barang juga diperbolehkan. Jumlahnya yang banyak seperti biji-bijian dan beberapa domba, kemudian dikumpulkan agar dapat digunakan Sultan pada waktu dia melakukan perjalanan atau diberikan kepada masyarakat yang miskin.

\section{Kebijakan Sosial Budaya dan Keagamaan}

Sultan Mahmud Ghazni semakin memperkokoh posisi Islam di India, keberhasilannya dalam mengembalikan posisi Islam melalui penaklukkan raja-raja Hindu dan melakukan islamisasi terhadap masyarakat India pada tahun 1020 M. Penopang keberhasilan tersebut ialah konsep ajaran Islam yang dibawanya, melalui penekanan persamaan derajat menggantikan sistem kasta yang berkembang di tengah masyarakat Hindu. Pada tahun 1020 M, Sultan Mahmud Gazni berhasil menaklukan raja-raja Hindu di wilayah India dan mengislamkannya. ${ }^{53}$

\footnotetext{
${ }^{51}$ Hamka, Sejarah Umat Islam, Jilid. III, Cet. IV (Jakarta: Bulan Bintang, 1981), hlm. 122.

${ }^{52}$ Muhammad Nazim, The Life and Times of Sultan Mahmud of Ghazna (Cambridge: The University Press, 1931), hlm. 133

${ }^{53}$ Dewan Redaksi, Ensiklopedi Islam (Cet. X; Jakarta: PT Ichtiar Baru van Hoeve, 2002), hal. 211.
} 
Salah satu hasil utama invasi Sultan Mahmud ke India adalah prevalensi budaya Iran di India. Sebenarnya Ghaznawiyah sangat kuat penampilan bersama dengan strategi militer-politik yang berkelanjutan di timur, meski dengan sebutan 'jihad' (perang suci melawan orang kafir), menyebabkan ekspansi kerajaan Islam ke arah utara dan timur wilayah India. Pada zaman Sultan Mahmud, tidak hanya itu Wilayah Ghaznawiyah di India meluas tetapi pintu Islam tetap ada dibuka ke timur dan tenggara. Dominasi Sultan di bagian Sutra Jalan mengakibatkan perkembangan interaksi budaya dengan India dan Cina. Di puncak kemegahannya, wilayah kekuasaan Ghaznawiyah membentang dari India dan pantai Samudra Hindia hingga Kharazm, Gorgan, Rey, Esfahan dan Kerman. Kerajaan besar Ghaznawiyah, dengan menyingkirkan banyak penghalang dan perbatasan, telah memberikan dasar untuk interaksi budaya yang berbeda, dan dengan mengirimkan ekspedisi ke India, Dinasti Ghaznawiyah adalah salah satu Dinasti yang memajukan pada bidang sastra dan budaya Iran. Dalam ekspedisi militer tersebut, terdapat kelompok budaya dan sarjana sastra yang menemani raja-raja Ghaznawiyah. Salah satu yang paling populer dari Farrukhi Sistani menggambarkan perjalanan jauh dengan Sultan Mahmud kepada Multan dan Somnath. Dengan bantuan material dan spiritual mereka, raja-raja Ghaznawiyah bermain peran penting dalam perkembangan budaya Iran di India.

\section{KESIMPULAN}

Berdasarkan uraian analisis dan pembahasan pada permasalahan di atas, maka penulis menarik kesimpulan yang dapat peroleh dari penelitian mengenai "Peran Mahmud Ghazni Terhadap Perkembangan Peradaban Islam, 388-421 H/ 998-1030 M" sebagai berikut.

Pertama, Alpataqin merupakan perintis pendirian Dinasti Ghaznawiyah, sedangkan Sabuktaqin mampu membentuk kekuatan Dinasti yang mapan dan menguasai wilayah yang luas sehingga diakui keberadaannya oleh Baghdad

Kedua, Pada masa pemerintahan Mahmud Ghazni berkuasa selama 34 tahun, pada masa ini pemerintahan Dinasti Ghaznawiyah mengalami era kejayaan. Kekuatan yang dimiliki mampu memperluas wilayah kekuasaan hingga mencapai wilayah India, bahkan berhasil menguasai Kashmir, Bathinda dan Peshawar pada 391-394 H/1001-1004 M. Pada tahun 1006 M menguasai Punjab, tahun 1009 menguasai Kangra, tahun 402-403 H/1011-1012 M menguasai Baluchistan, selanjutnya tahun 405-406 H/1014-1015 M menguasai Delhi. Melimpahnya sumber kekayaan dan wilayah yang luas menjadikan perekonomian negeri ini sangat kuat, sehingga mampu memajukan dan memakmurkan negeri.

Mahmud Ghazni membangun fasilitas-fasilitas belajar dan mengajar, sehingga mencetak sastrawan dan ilmuwan handal, antara lain:

a. Abu Al-Qasim bin Hasan Al-Maimanda. Di samping seorang penyair, juga sebagai menteri kepercayaan Mahmud Ghazni. Bahkan mempunyai cita-cita yang tinggi dan ahli dalam strategi perang didukung dengan wawasan yang luas serta terkenal sebagai sastrawan yang handal.

b. Badi' Al-Zaman Al-Hamdani. Badi' Al-Zaman Al-Hamdani seorang sastrawan yang terkenal di masanya. Hamdani sudah menulis enam belas bait Syair yang isinya mengagungkan, memuliakan dan banyak memuji Mahmud Ghazni.

c. Abu Mansur Al-Tsa'alabi. Abu Mansur Al-Tsa'alabi sebagai penyair dengan aktif menulis sya'ir berisi banyak pujian kepada kepemimpinan Mahmud Ghazni.

d. Abu Al-Nashr Muhammad bin Abd Al-Jabbar Al-Utbi. Abu Al-Nashr Muhammad adalah ahli sejarah dan seorang sastrawan terkenal, kitab karangannya yang teerkenal yaitu Al-Yamani, kitab ini diperesembahkan untuk gelar Sultan Mahmud Ghazni (Yamin al-Daulah). Kitab ini berisi sejarah bani Ghaznawiyah dan beberapa pencapaian terhadap kemajuan pemerintahan Mahmud Ghazni. 
e. Abu Al-Fath Al-Busti. Di samping seorang penyair, Abu Al-Fath Al-Busti juga sebagai penasehat hukum dan sekretaris pribadi Mahmud Ghazni. Abu Al-Fath Al-Busti merupakan penyair besar, tulisan sya'irnya bermakna sangat dalam sehingga sulit difahami maknanya terkecuali oleh orang-orang yang ahli dalam bahasa/ lughoh.

Perhatian terhadap ilmu pengetahuan sangat besar selama masa pemerintahannya (387-421 $\mathrm{H} / 997-1030 \mathrm{M}$ ), hal tersebut bisa diketahui dari beberapa aktivitas-aktivitas ilmiah antara lain:

d. Mempelopori penulisan tafsir Al-qur'an sesuai ilmu Nahwu dan ilmu Saraf dan berpedoman pada Hadits yang Sahih.

e. Mendirikan Madrasah untuk kegiatan belajar.

f. Memberi anjuran untuk banyak ulama dan filusuf Islam seperti Al-Biruni, Ibnu Sina, Abu Nasr al-Arraq dan Ibnu Khamar Abu Sahl al-Masihi supaya bisa mengambil manfaat dari ilmu mereka.

Ketiga, Mahmud Ghazni dalam memajukan peradaban Islam di India, melakukan beberapa strategi untuk dapat mencapai masa kejayaan serta kemajuan Islam. Adapun strategi yang dilakukan Mahmud Ghazni untuk memajukan peradaban Islam di India dengan melakukan kebijakan dalam bidang politik dan pemerintahan, dalam bidang militer, melakukan beberapa kebijakan dalam bidang ekonomi serta kebijakan dalam bidang sosial budaya dan keagamaan.

\section{DAFTAR PUSTAKA}

\section{Buku:}

Abu Bakar, Istianah. Sejarah Peradaban Islam. Malang: UIN-Malang Press. 2008.

Ahmad, Jamil. Seratus Muslim Terkemuka. Jakarta: Pustaka Firdaus. 1984.

al-Sirjani, Raghib. Sumbangan Peradaban Islam pada Dunia. Jakarta: Pustaka al-Kautsar. 2011.

al-'Usairy, Ahmad. Sejarah Islam, terj. Samson Rahman. Cet. VI. Jakarta: Akbar Media Nusantara. 2008.

Amin, Munir S. Sejarah Peradaban Islam. Jakarta: Amzah. 2009.

Best, J.W. Metodologi Penelitian, terjemahan Sanapsiah Faisal dan Mulyadi. Surabaya: Usaha Nasional. 1999.

Bosworth, C.W. Dinasti-Dinasti Islam. Terjemahan Ilyas Hasan. Bandung: Mizan. 1993.

Dewan Redaksi Ensiklopedi Islam, Ensiklopedi Islam Cet. 2. Jakarta: PT. Ichtiar Baru Van Hoeve. 1994.

\section{2.}

Edyar, Busman. Sejarah Perdaban Islam. Jakarta: Pustaka Asatruss, 2009.

Haif, Abu. Eksistensi Mamluk dalam Membangun Peradaban Islam pada Abad Kegelapan. Makasar: Alauddin University. 2012.

Hamka. Sejarah Umat Islam Jilid. III, Cet. IV. Jakarta: Bulan Bintang. 1981.

Hasjmy, A. Sejarah Kebudayaan Islam. Jakarta: Bulan Bintang. 1979.

Hartatik, Endah Sri. Metode Penelitian Sejarah. Yogyakarta: Magnum Pustaka Utama. 2018.

Hitti, Philip K. History of Arabs: Rujukan Induk dan Paling Otoritatif Tentang Sejarah Peradaban Islam. Terj. R. Cecep Lukman Yasin dan Dedi Slamet Riyadi. Jakarta: Serambi Ilmu Semesta. 2007.

Karim, Abdul M. Islam di Asia Tengah. Yogyakarta: Bunga Grafis Production. 2003.

$$
2009 .
$$


Kuntowijoyo. Metodologi Sejarah. Yogyakarta: Tiara Wacana. 2003.

Lapidus, Ira. M. Sejarah Sosial Umat Islam, terjemahan Ghufron A. Mas'adi. Jakarta: PT. Raja Grafindo Persada. 2000.

M. Faal, Fahsin. Sejarah Kekuasaan Islam Cet. I. Jakarta: CV Artha Rivera. 2008.

Nazim, Muhammad. The Life and Times of Sultan Mahmud of Ghazna. Cambridge: The University Press. 1931.

Notosusanto, Nugroho. Norma-norma Dasar Penelitian dan Penulisan Sejarah. Jakarta: Pusat Sejarah ABRI DEPHANKAM, 1971.

Poerwadarminta, W.J.S. Kamus Besar Bahasa Indonesia Cet. IV. Jakarta: Balai Pustaka. 1993.

Sugiyono. Metode Penelitian Kombinasi (Mix Methods). Bandung: Alfabeta, 2015.

Sunanto, Musyrifah. Sejarah Islam Klasik. Jakarta: Prenada. 2007.

Yatim, Badri. Sejarah Peradaban Islam. Jakarta: Raja Grafindo Persada. 2002. . Sejarah Kebudayaan Islam II. Jakarta: Ditjen Binbaga Islam. 2001.

Watt, Montgomery W. Kejayaan Islam, terjemahan Kartono Hadikusumo. Yogyakarta: Tiara Wacana. 1990

\section{Skripsi:}

Ali, Nasihudi M., "Kepemimpinan Shah Jahan di Kesultanan Mughal (1628-1658 M)”, Skripsi. Jogjakarta: Fakultas Adab dan Humaniora UIN Sunan Kalijaga. 2017.

Firdaus, Rian, "Dinasti Ghaznawiyah di Afghanistan 366-582 H/977-1186 M (Kajian Historis tentang Peranannya terhadap Perkembangan Peradaban Islam)", Skripsi. Makassar: Jurusan Sejarah dan Kebudayaan Islam Fakultas Adab dan Humaniora UIN Alauddin, 2014.

\section{Jurnal dan Artikel:}

Faidi, Ahmad, "Akulturasi Budaya Islam dan India: Tinjauan Historis terhadap Dialektika Kebudayaan Islam di India", Journal of History and Cultural Hiritage. Salatiga: Mahesa Research Center, 2020. Volume 1 (2), 46-54.

Nunzairina, "Dinasti Abbasiyah: Kemajuan Peradaban Islam, Pendidikan dan Kebangkitan Kaum Intelektual", Jurnal Sejarah Peradaban Islam. Medan: Program Studi Peradaban Islam, Fakultas Ilmu Sosial, UIN Sumatera Utara, 2020. Volume 3 Nomor 2, 93-103.

Sadari, "Asimilasi Spektrum Peradaban Islam dan Keberislaman di India", Misykat, Volume 05, Nomor 01, 2020. 